\title{
ОБЗОРЫ/REVIEWS
}

https://doi.org/10.30766/2072-9081.2021.22.5.627-640

УДК 542.06:631.8

Биосинтез наночастиц метаммов и оксидов метаммов

и их использование в качестве компонентов удобрений

и препаратов дия растениеводства (обзор иитературы)

(C) 2021. Г. Ю. Рабинович, Н. А. Аюбимова

ФГБНУ ФИЦ "Почвенный институт им. В. В. Докучаева", г. Москва,

Российская Федераиия

Перспективным направлением в сельском хозяйстве является использование наночастиц металлов в качестве наноудобрений, которые позволяют повысить урожайность сельскохозяйственных культур и при этом минимизировать частоту применения удобрений за счет долгосрочного высвобождения питательных вещцеств. Одним из наиболее безопасных с экологической точки зрения и дешевых способов синтеза наночастиц металлов является биосинтез с использованием растительных экстрактов. В процессе окислительно-восстановительной реакции белки, углеводы, органические кислоты, фенолы и другие метаболиты способны передавать электроны катионам металлов, восстанавливая их заряд до нулевого в нанометровом маситабе. В данной статье на основе публикаций по изучаемому вопросу исследователей из Соединенных Штатов Америки, стран Европы и Ближнего Востока, Китая и Индии описан биосинтез наночастиц оксида цинка, меди и оксида меди, железа и оксида железа, а также марганца и оксида марганца с использованием растительных экстрактов, и представлены данные по использованию указанных металлов и их оксидов в качестве наноудобрений и препаратов для растениеводства. Показано, что использование наночастиц металлов и их оксидов в качестве удобрений более эффективно по сравнению с обычными соединениями, используемыми в качестве удобрений. Вероятно, это связано с тем, что наночастицам легче проникнуть через растительную мембрану, а также перейти в доступную для растений форму по сравнению с обычными аналогами. Положительный эффект влияния наночастиц на растения выражен в удлинении корней и побегов модельных растений и увеличении биомассы проростков. Кроме того, в листьях увеличивается количество хлорофилла, а также изменяются некоторые биохимические процессы, например, увеличивается количество антиоксидантных ферментов, что позволяет повысить стрессоустойчивость растений.

Ключевые слова: растительные экстракты, биосинтез наночастии, железо, медь, марганеи, ијик, наноудобрение

Благодарности: работа выполнена при поддержке Минобрнауки РФ в рамках Государственного задания ФГБНУ ФИЦ «Почвенный институт им. В. В. Докучаева» (тема № 0651-2019-0007).

Авторы благодарят рецензентов за их вклад в экспертную оценку этой работы.

Конфликт интересов: авторы заявили об отсутствии конфликта интересов.

Для цитирования: Рабинович Г. Ю., Любимова Н. А. Биосинтез наночастиц металлов и оксидов металлов их использование в качестве компонентов удобрений и препаратов для растениеводства: обзор литературы. Аграрная наука Евро-Северо-Востока. 2021;22(5):627-640. DOI: https://doi.org/10.30766/2072-9081.2021.22.5.627-640

$$
\text { Поступила: 27.05.2021 Принята к публикации: 30.08.2021 Опубликована онлайн: 27.10.2021 }
$$

\section{Biosynthesis of metal nanoparticles and metal oxidesand their use as components of fertilizers and preparations for plant growing (literature review)}

\author{
(C) 2021. Galina Yu. Rabinovich, Nadezhda A. Lyubimova ${ }^{\varpi}$ \\ Federal Research Centre V. V. Dokuchaev Soil Science Institute, Moscow, \\ Russian Federation
}

A promising direction in agriculture is the use of metal nanoparticles as nanofertilizers, which can increase the yield of agricultural crops and, at the same time, minimize the frequency of fertilization due to the long-term release of nutrients. One of the environmentally safest and cheapest methods of synthesizing metal nanoparticles is biosynthesis using plant extracts. During the redox reaction, proteins, carbohydrates, organic acids, phenols and other metabolites are able to transfer electrons to metal cations, restoring their charge to zero on the nanometer scale. This article, based on publications on the issue under study by authors from the United States of America, Europe and the Middle East, China and India, describes the biosynthesis of nanoparticles of zinc oxide, copper and copper oxide, iron and iron oxide, as well as manganese and manganese oxide using the formation of plant extracts, and data on the use of these metals and their oxides as nanofertilizers and preparations for plant growing are presented. It has been shown that the use of metal nanoparticles and their oxides as fertilizers is more effective than conventional compounds used as fertilizers. This is probably due to the fact that it is easier for nanoparticles to penetrate through the plant membrane, as well as to pass into a form accessible to plants in comparison with

Аграрная наука Евро-Северо-Востока /

Agricultural Science Euro-North-East. 2021;22(5):627-640 
conventional analogs. The positive effect of the influence of nanoparticles on plants is expressed in the elongation of the roots and shoots of model plants and an increase in the biomass of seedlings. In addition, the amount of chlorophyll in the leaves increases, and some biochemical processes also change, for example, the amount of antioxidant enzymes increases, which makes it possible to increase the stress resistance of plants.

Key words: plant extracts, biosynthesis of nanoparticles, iron, copper, manganese, zinc, nanofertilizer

Acknowledgments: the research was carried out under the support of the Ministry of Science and Higher Education of the Russian Federation within the state assignment of the FRC V. V. Dokuchaev Soil Science Institute (theme No. 0651-2019-0007). The authors thank the reviewers for their contribution to the peer review of this work.

Conflict of interest: the authors declare no conflict of interest.

For citations: Rabinovich G. Yu., Lyubimova N. A. Biosynthesis of metal nanoparticles and metal oxides and their use as components of fertilizers and preparations for plant growing: literature review. Agrarnaya nauka Evro-Severo-Vostoka = Agricultural Science Euro-North-East. 2021;22(5):627-640. (In Russ.). DOI: https://doi.org/10.30766/2072-9081.2021.22.5.627-640

Received: 27.05.2021 Accepted for publication: 30.08.2021 Published online: 27.10.2021

В контексте устойчивого сельского хозяйства применение инновационных нанотехнологий, включая разработку удобрений, рассматривается как перспективное направление. В связи с этим в настоящее время по всему миру проводятся исследования, направленные на разработку наноудобрений, позволяющих повысить урожайность сельскохозяйственных культур, и при этом минимизировать вред агрохимикатов в отношении окружающей среды [1].

Существует три основных типа наноудобрений: наноразмерные удобрения (синтезированные наночастицы, в том числе наночастицы металлов и оксидов металлов), наноразмерные добавки (объемные продукты с наноразмерными добавками) и наноразмерные покрытия или материалы-хозяева (продукт, покрытый нанополимером или загруженный наночастицами) [2].

В отличие от традиционных при использовании удобрений с наночастицами высвобождение питательных веществ в почву происходит постепенно, что в свою очередь приводит к повышению эффективности элементов и сокращению частоты внесения удобрений, а также к снижению загрязненности почвы и негативных эффектов, вызванных чрезмерным потреблением удобрений [3]. Кроме того, использование наноудобрений сокращает расходы на транспортировку и внесение. Еще одним преимуществом использования наноудобрений является то, что они могут быть синтезированы в соответствии с потребностями в питательных веществах предполагаемых культур. Наноудобрения увеличивают биодоступность питательных веществ за счет их высокой удельной поверхности, маленьких размеров и высокой реакционной способности. С другой стороны, обеспечивая сбалансированное питание, наноудобрения позволяют растениям бороться с различными биотиче- скими и абиотическими стрессами с общими очевидными преимуществами [4].

Для синтеза наночастиц металлов используются различные методы, которые подразделяются на две основные группы это методы «снизу вверх» и «сверху вниз». В методах «сверху вниз» исходный материал объемный, а наночастицы формируются за счет физических, химических и механических процессов, тогда как в методах «снизу вверх», наоборот, исходным материалом являются атомы или молекулы. К методам «сверху вниз» относятся механическое фрезерование (используется высокоэнергетическая шаровая мельница, механохимический синтез), термическая и лазерная абляция (лазерное облучение используется для уменьшения размера частиц до наноуровня), а также ионное распыление (метод включает испарение твердого тела путем распыления пучком ионов инертного газа). Методы «снизу вверх» в свою очередь делятся на твердотельные (методы физического и химического осаждения из паровой фазы), методы синтеза в жидком состоянии (золь-гель метод, химическое восстановление, гидротермальный и сольвотермический методы), газофазные методы (спрей-пиролиз, лазерный и пламенный пиролиз) и методы зеленого синтеза (используются бактерии, грибы, растения и экстракты растений) [5]. С другой стороны, методы синтеза наночастиц можно разделить на три большие группы: физические, химические и биологические. В биологических методах, которые также называют методами биовосстановления, биосинтеза или зеленого синтеза, для синтеза наночастиц металлов и оксидов металлов используют биологические системы, такие как бактерии, грибы, вирусы, дрожжи, актиномицеты и растения. При этом биологические методы условно можно разделить на три 
категории: биогенный синтез с использованием микроорганизмов, биогенный синтез с использованием биомолекул в качестве матриц и биогенный синтез с использованием растительных экстрактов [6].

По своей сути зеленый синтез наночастиц металлов является окислительновосстановительной реакцией, в которой клеточные и внеклеточные компоненты, такие как белки, углеводы, органические кислоты, фенолы и другие метаболиты способны передавать электроны катионам металлов, восстанавливая их заряд до нулевого в нанометровом масштабе. Функциональными группами, участвующими в синтезе наночастиц, являются альдегидные и кетогруппы, аминогруппа, карбоксильная, гидроксильная и сульфгидрильные группы, так что практически любое биологическое соединение, содержащее эти группы, можно использовать для преобразования ионов металлов в наночастицы [7].

Среди факторов, влияющих на синтез различных частиц, наиболее значимым является температура, которая влияет на размер и форму наночастиц, а также на скорость синтеза (с увеличением температуры возрастает скорость реакции и формирование зародышевых центров). Наряду с температурой время реакции также существенно влияет на морфологию наночастиц, а именно с увеличением времени реакции их размер увеличивается. Кроме температуры, важную роль в формировании наночастиц играет уровень $\mathrm{pH}$, с помощью которого можно регулировать образование зародышевых центров (чем выше $\mathrm{pH}$ тем больше зародышевых центров) [8].

Синтез наночастиц с использованием растительных экстрактов условно можно разделить на три фазы: активации, роста и завершения. Фаза активации является начальной стадией, в которой ионы металлов извлекаются из прекурсора под действием растительных метаболитов - биомолекул, обладающих восстановительной способностью. При этом ионы металлов восстанавливаются до нульвалентного состояния, и происходит зародышеобразование из восстановленных атомов металла. В фазу роста формируются наночастицы различной морфологии, тогда как в фазу завершения полученные частицы стабилизируются метаболитами растений и становятся максимально активными [9].

В настоящее время во Всероссийском НИИ мелиорируемых земель разрабатывается и исследуется как в лабораторных условиях, так и в полевом мелкоделяночном опыте биопрепарат, содержащий в своем составе наночастицы меди, марганца, цинка и железа - важных микроэлементов, участвующих в различных биохимических процессах. В связи с этим изучение иностранной литературы по данной тематике является для нас весьма актуальным.

Цель обзора - рассмотреть методы биосинтеза наночастиц металлов и их оксидов (цинк, медь, марганец и железо) с использованием растительных экстрактов, а также перспективы их использования в качестве удобрений и препаратов для растениеводства и их влияние на растительный организм.

Материал и методы. В обзоре представлены научные публикации по изучаемому вопросу авторов из Европы, Соединенных Штатов Америки, стран Ближнего Востока, Китая и Индии. Для отбора научных статей провели поиск источников по ключевым словам (plant extracts, biosynthesis of nanoparticles, iron, copper, manganese, zinc, nanofertilizer) в поисковой системе Google Scholar, а также через сайт Американского химического общества (pubs.acs.org) и сайт, принадлежащий издательству Elsevier (www.sciencedirect.com). Для обзора были выбраны статьи, опубликованные в 2013-2020 годах, однако большее внимание уделялось статьям за последние три года.

Основная часть. Получение и применение наночастии оксида иинка в растениеводстве. Цинк (Zn) - один из основных микроэлементов, необходимых для роста и развития растений. Он обеспечивает каталитическую активность различных метаболических ферментов, включая дегидрогеназы, альдолазы, изомеразы, трансфосфорилазы, РНК- и ДНКполимеразы. Участвует в синтезе триптофана, делении клеток, поддержании структуры и потенциала мембран, фотосинтезе и в синтезе белка. Биологически синтезированные наночастицы оксида цинка ( $\mathrm{ZnO})$ быстро транспортируются в растения и включаются в метаболические процессы. С другой стороны, наночастицы ZnO могут служить важными питательными микроэлементами для роста и развития растений, а также выступать в качестве альтернативного наноудобрения по сравнению с обычными химическими удобрениями для эффективного использования питательных веществ растениями [10]. 
Важно, что способ синтеза наночастиц $\mathrm{ZnO}$ (ультразвуковой, влажно-химический и гидротермальный) влияет на их размер и форму. Так было показано, что в процессе биосинтеза наночастиц с использованием экстракта коры арджуны (Terminalia arjuna) при обработке ультразвуком, влажно-химическом и гидротермальном воздействии средний размер наночастиц составил 43, 34 и 21 нм соответственно. Анализ удельной площади поверхности образцов показал, что при использовании гидротермального метода формируются наночастицы $\mathrm{ZnO}$ с большей площадью поверхности $\left(217 \mathrm{~m}^{2} / \Gamma\right)$, чем при влажно-химическом методе и использовании ультразвука (191 и $198 \mathrm{~m}^{2} / \Gamma$ соответственно). Изображения подготовленных наночастиц, полученные с помощью сканирующей электронной микроскопии (СЭМ), показали, что при обработке ультразвуком и влажно-химическом методе форма частиц близка к сферической. Однако наночастицы $\mathrm{ZnO}$, полученные гидротермальным способом, показывали иерархическую сферическую сверхструктуру, которая формируется из-за послойного осаждения более мелких наночастиц [11].

На размер и морфологию получаемых наночастиц также может повлиять способ получения экстракта. Так, при использовании экстракта, полученного выдерживанием порошка листьев габитуса (Suaeda aegyptiaca) в бидистиллированной воде в течение 48 часов в темноте, происходило формирование крупных и неоднородных агломератов наночастиц $\mathrm{ZnO}$. Тогда как при использовании экстракта того же растения, обработанного микроволнами (мощность волн 270 Вт) вместо выдержки в темноте, получали наночастицы сферической формы от 40 до 76 нм [12].

Наночастицы оксида цинка были синтезированы с использованием $1 \mathrm{M}$ раствора нитрата цинка и экстракта из корня кодонопсиса ланцентного (Codonopsis lanceolata), в химический состав которого включены различные химически активные танины, сапонины, полифенолы, алкалоиды, эфирные масла и стероиды. Согласно данным просвечивающей электронной микроскопии (ПЭМ), в результате синтеза сформировались частицы размером около 500 нм с цветочной структурой [13].

В работе [14] для получения наночастиц $\mathrm{ZnO}$ использовали экстракт листьев кустарника C. zeylanica и 0,2 М раствор ацетата цинка. По данным СЭМ, в результате синтеза форми- руются наночастицы $\mathrm{ZnO}$ со средним размером 28-30 нм.

W. Ahmad, D. Kalra [15] синтезировали наночастицы оксида цинка размером от 20 до 25 нм с использованием экстракта листьев молочая Euphorbia hirta и нитрата цинка. Цвет раствора получили бело-желтым, что свидетельствовало о формировании наночастиц $\mathrm{ZnO}$. Кроме того, для получения наночастиц потребовалось дополнительное прокаливание осадка в муфельной печи при $400{ }^{\circ} \mathrm{C}$ в течение двух часов.

K. Elumalai с соавт. [16] синтезировали наночастицы $\mathrm{ZnO}$ с использованием экстракта листьев тамаринда индийского (Tamarindus indica) и гексагидрата нитрата цинка, смесь которых кипятили до образования пасты темно-желтого цвета. Затем пасту переносили в керамический тигель и нагревали в печи при $400{ }^{\circ} \mathrm{C}$ в течение трех часов, что привело к образованию порошка светло-желтого цвета. В результате были получены сферические наночастицы $\mathrm{ZnO}$ размером от 16 до 31 нм. При этом средний размер частиц составил 21 нм.

Для получения наночастиц $\mathrm{ZnO}$ в качестве восстановителя использовали экстракт семян тмина, который смешивали с нитратом цинка концентрацией $0,001 \mathrm{M} \mathrm{(10} \mathrm{мл} \mathrm{экстракта}$ и 90 мл нитрата). Согласно полученным микрофотографиям, синтезированные при оптимальном $\mathrm{pH} 8,7$ наночастицы в основном имели сферическую и овальную форму с размерами от 3 до 29 нм и средним диаметром около 7 нм [17]. Наночастицы $\mathrm{ZnO}$ сферической формы со средним диаметром 70 нм синтезировали, используя в качестве восстановителя экстракт пассифлоры голубой (Passiflora caerulea L.) и 0,001 М раствор ацетата цинка. О синтезе наночастиц свидетельствовало появление желтой окраски раствора и появление осадка [18].

В работе [19] описан биосинтез наночастиц $\mathrm{ZnO}$ сферической формы и размером от 25 до 40 нм из экстракта кожуры рамбутана (Nephelium lappaceum L.), который по каплям добавляли к $0,1 \mathrm{M}$ водному раствору гексагидрата нитрата цинка. В данном случае для получения чистых наночастиц $\mathrm{ZnO}$ также потребовалось прокаливание сухого осадка в муфельной печи при $450{ }^{\circ} \mathrm{C}$.

В работе [20] синтезировали наночастицы $\mathrm{ZnO}$ размером от 1 до 7 нм с использованием 0,001 М раствора нитрата цинка и фильтрата, полученного инкубацией гриба Aspergillus fumigatus TFR-8, выращенного поверхностным 
жидкофазным методом в водном растворе, и исследовали их влияние на фосфат-мобилизующие ферменты в ризосфере и на содержание камеди в зернах горохового дерева (Cyamopsis tetragonoloba L.). В результате было обнаружено, что при опрыскивании вегетирующих растений наночастицами $\mathrm{ZnO}$ в концентрации 10 мг/л через две недели после всходов в 1,3 раза увеличилась длина побега и в 1,6 раза длина корня растения, тогда как сухая биомасса возросла в 2,4 раза по сравнению с контролем. При этом содержание хлорофилла, общего растворимого белка листьев и фосфора в растении увеличилось на 276,27 и $11 \%$ соответственно по сравнению с контролем. Представленные в данной работе результаты свидетельствовали, что популяция ризосферных микроорганизмов увеличилась на $12-14 \%$ за счет применения наночастиц $\mathrm{ZnO}$. Кроме того, в ризосфере образца, обработанного наночастицами $\mathrm{ZnO}$, по сравнению с контролем повысилась активность фитазы в 1,7 раза, кислой и щелочной фосфатазы в 1,7 и 1,5 раза соответственно. Отмечалось, что содержание камеди и ее вязкость в семени растений, опрыскиваемых наночастицами $\mathrm{ZnO}$, были выше, чем в контроле (содержание камеди в опытном и контрольном образцах составило 31 и $29 \%$ соответственно, а показатель вязкости фиксировался на уровне 3126 и $3030 \mathrm{мПа} \cdot \mathbf{c})$.

Сферические наночастицы $\mathrm{ZnO}$, средний размер которых составлял 11 нм, были синтезированы in vitro с использованием фермента альфа-амилазы, а их влияние на растения было изучено на примере культуры Brassica juncea (горчица сарептская). Было обнаружено, что максимальная скорость прорастания семян горчицы $(80 \pm 2 \%)$ наблюдалась при их обработке наночастицами концентрацией 20 мкг/мл, тогда как повышение концентрации $\mathrm{ZnO}$ на 10 мкг/мл привело к снижению скорости прорастания до $53 \pm 1 \%$, что существенно ниже, чем в контроле $(73 \pm 2 \%)$. При этом длина корня и побега были больше у растений, обработанных наночастицами $\mathrm{ZnO}$ концентрацией 20 мкг/мл, по сравнению с контролем, а наименьшую длину побега наблюдали у растений, обработанных наночастицами ZnO концентрацией 30 мкг/мл. Таким образом, наночастицы $\mathrm{ZnO}$ концентрацией 20 мкг/мл могут быть использованы в качестве наноудобрений [21].
В исследовании Е. Yusefi-Tanha c соавт. [22] сравнивалось влияние наночастиц $\mathrm{ZnO}$ различной морфологии и размера (сферические размером 38 нм, цветочкоподобные (59 нм) и стержнеобразные (500 нм)) на продуктивность и качество растений сои. Было обнаружено, что при дозе наночастиц $\mathrm{ZnO}$ 160 мг Zn/кг почвы максимальный урожай семян (25 г с одного растения) был получен при использовании сферических наночастиц размером 38 нм. Увеличение дозы $\mathrm{ZnO}$ до 400 мг/кг почвы приводило к снижению выхода семян. При этом с увеличением концентрации наночастиц от 40 до 160 мг $\mathrm{Zn} /$ кг почвы наблюдалось линейное снижение содержания перекиси водорода и малонового диальдегида независимо от формы и размера частиц, что предполагает защитное действие наночастиц, используемых в малых концентрациях. Также наночастицы $\mathrm{ZnO}$ в диапазоне концентраций от 40 до 160 мг $\mathrm{Zn} /$ кг почвы повлияли на активность супероксиддисмутазы, каталазы и пероксидазы в листьях сои: при увеличении концентрации активность этих антиоксидантных ферментов значительно снижалась независимо от формы и размера частиц. Тогда как при концентрации $\mathrm{ZnO} 400$ мг $\mathrm{Zn} /$ кг почвы активность этих ферментов значительно увеличивалась для всех соединений $\mathrm{Zn}$, за исключением обработки наночастицами $\mathrm{ZnO}$ в форме стержня размером 500 нм, которая не показала значительной разницы в активности ферментов по сравнению с контролем [22].

В исследовании [23] наночастицы оксида цинка были синтезированы с использованием богатой сапонином фракции водного экстракта эклипты белой (Eclipta alba), и изучено их влияние на рост растений жемчужного проса. В лабораторных и тепличных условиях обработка семян синтезированными наночастицами значительно улучшила их всхожесть и жизнеспособность, высоту растений, сырую и сухую массу проростков. Наночастицы $\mathrm{ZnO}$ концентрацией 50 ppm применяли для обработки семян и опрыскивания листьев, что привело к снижению заболеваемости проса ложной мучнистой росой на $35 \%$ по сравнению с необработанным контролем. Проростки, обработанные наночастицами $\mathrm{ZnO}$, показали высокую лигнификацию и отложение каллозы при заражении ложной мучнистой росой. Анализ защитных ферментов показал, что обработка наночастицами значительно усиливала активность пероксидазы, фенилалани- 
наммиаклиазы, липоксигеназы и полифенолоксидазы по сравнению с необработанным контролем. Полученные результаты показали, что синтезированные наночастицы $\mathrm{ZnO}$ могут не только содействовать росту, но способны вызывать системную резистентность жемчужного проса против $S$. graminicola и могут быть эффективно использованы для борьбы с ложной мучнистой росой [23].

Влияние наночастиц $\mathrm{ZnO}$ и $\mathrm{ZnSO}_{4}$ на листья озимой пшеницы (Triticum aestivum L.) и качество зерна изучали в полевых условиях, при этом распределение и видовой состав Zn в зерне исследовали с помощью Х-лучевой флуоресцентной микроскопии и рентгеновской абсорбционной спектроскопии. Хотя ни одно из двух соединений $\mathrm{Zn}$ не улучшало урожай или качество зерна, оба повышали концентрацию $\mathrm{Zn}$ в зерне (средние приращения составляли 5 и 10 мг/кг при обработке $\mathrm{ZnSO}_{4}$ и наночастицами $\mathrm{ZnO}$ соответственно). При всех обработках Zn в основном находился внутри алейронового слоя и снаружи эндосперма, хотя нанесение наночастиц $\mathrm{ZnO}$ также немного увеличивало содержание $\mathrm{Zn}$ в самом эндосперме. Было обнаружено, что $\mathrm{Zn}$ в зерне присутствует в виде фосфата $\mathrm{Zn}$, и это не зависит от формы, которую использовали для его нанесения. Эти результаты показали, что внекорневая подкормка злаковых культурнаночастицами ZnO может стать многообещающим подходом к биообогащению растений цинком, необходимому для улучшения здоровья человека [24].

Получение и применение наночастич железа и оксида железа в растениеводстве. Железо (Fe) является важным питательным веществом, которое в незначительных количествах требуется растениям для поддержания правильного роста и развития. Недостаток или избыток железа приводит к нарушению основных метаболических и физиологических процессов растений, что сопровождается снижением урожайности. Следовательно, внесение $\mathrm{Fe}$ является обязательным для оптимизации урожайности сельскохозяйственных культур [3].

Y. Vitta c соавт. [7] синтезировали наночастицы железа с использованием водного экстракта эвкалипта (Eucalyptus robusta $\mathrm{Sm}$.), листья которого содержат фенольные соединения, такие как сиринговая кислота, эпикатехин, кверцетин и галловая кислота, робустаол $\mathrm{B}$, эвкалиптин и другие полифенолы. Для синтеза наночастиц железа использовали экстрак- ты концентрацией 0,01 и 0,005 г/мл. Кроме того, варьировалась концентрация соли Мора $\left(\mathrm{NH}_{4}\right)_{2} \mathrm{Fe}\left(\mathrm{SO}_{4}\right) \quad 6 \mathrm{H}_{2} \mathrm{O}(0,1 \mathrm{M}, 1$ мМ и 5 мM), a также соотношение экстракта и раствора соли $(1: 1,2: 1$ и 1:2). Полученную смесь экстракта и соли обрабатывали ультразвуком при $40{ }^{\circ} \mathrm{C}$ в течение 30 минут. Об образовании наночастиц свидетельствовало появление в растворе черного цвета. Определение размера и морфологии наночастиц железа с использованием атомно-силовой микроскопии показало, что размер частиц увеличивается при возрастании концентрации экстракта и раствора соли Мора. Например, при концентрации прекурсора железа 1 мМ и концентрации экстракта 0,005 г/мл было замечено, что распределение наночастиц по размеру очень узкое (от 0,2 до 2,0 нм), со средним размером около 0,8 нм. Тогда как при более высоких концентрациях прекурсора полученные наночастицы железа склонны к агрегации [7].

При получении наночастиц железа (прекурсор - 0,001 М раствор $\mathrm{FeCl}_{3}$ ) и меди (прекурсор - 0,001 $\mathrm{M}$ раствор $\mathrm{CuSO}_{4}$ ) использовали экстракты листьев зеленого и черного чая. В процессе синтеза наночастиц наблюдалось изменение цвета растворов с желтого на черный (железо) и с синего на темно-коричневый (медь). Кроме того, в процессе синтеза рН раствора снизился с 5,12-5,16 до 2,88-3,65 ед. после восстановления. СЭМ-изображения показали, что синтезированные наночастицы железа и меди имеют агломерированные и сферические формы с диаметром в диапазоне 42-60 и 26-40 нм соответственно [25]. Однако наночастицы железа размером меньше 25 нм были приготовлены с использованием экстракта зеленого чая в качестве восстановителя и 0,1 М раствора нитрата железа в этиленгликоле, объемное соотношение которых было 1:2 [26].

Для получения наночастиц железа размером 12-23 нм использовали экстракт кожуры манго и 0,5 $\mathrm{M}$ раствор $\mathrm{FeCl}_{3} \cdot 6 \mathrm{H}_{2} \mathrm{O}$ в объемном соотношении экстракта и раствора соли 3:1. При добавлении экстракта кожуры манго к раствору хлорида железа наблюдалось постепенное изменение окраски раствора от светло-коричневого до темно-коричневого, что свидетельствовало о формировании наночастиц железа [27].

Наночастицы $\mathrm{Fe}_{3} \mathrm{O}_{4}$ были синтезированы с использованием экстракта плодов курупиты гвианской (Couroupita guianensis) и 0,1 M pacтвора гексагидрата хлорида железа. Важно 
отметить, что о получении наночастиц $\mathrm{Fe}_{3} \mathrm{O}_{4}$ свидетельствовало изменение цвета раствора: синтезированные наночастицы были от светлокрасного до темно-коричневого цвета, тогда как раствор хлорида железа был золотистожелтым. Согласно ПЭМ-изображению, размер полученных наночастиц варьировал от 7 до 77 нм, а средний размер составил $17 \pm 10$ нм [28].

F. Buazar c coaвт. [29] синтезировали наночастицы $\mathrm{Fe}_{3} \mathrm{O}_{4}$, используя экстракт клубней картофеля в качестве восстановителя и сульфата железа $\left(\mathrm{FeSO}_{4} \cdot 5 \mathrm{H}_{2} \mathrm{O}\right), 3$ г которого добавляли к 40 мл экстракта и нагревали до $80{ }^{\circ} \mathrm{C}$, а затем смесь обрабатывали ультразвуком в течение 15 минут для повышения химической активности и улучшения кинетики реакции путем гомогенизации раствора. После этого к раствору постепенно добавляли 5 мл гидроксида натрия, чтобы получить $\mathrm{pH}=8$, a после полученный раствор перемешивали в течение 20 минут при $85{ }^{\circ} \mathrm{C}$. Полученный осадок отфильтровывали, промывали и высушивали при $70{ }^{\circ} \mathrm{C}$. Затем полученный осадок прокаливали в печи с воздушным нагревом в течение 30 мин при $600{ }^{\circ} \mathrm{C}$ для получения свежего нанопорошка $\mathrm{Fe}_{3} \mathrm{O}_{4}$. В процессе синтеза цвет раствора изменился с желтого (цвет экстракта) на черный, что свидетельствовало о формировании наночастиц $\mathrm{Fe}_{3} \mathrm{O}_{4}$. Формирование наночастиц $\mathrm{Fe}_{3} \mathrm{O}_{4}$ в этом процессе могло проходить в два этапа. На первом этапе $\mathrm{Fe}(\mathrm{OH})_{2}$ образовывался в водном растворе, когда $\mathrm{FeSO}_{4} \cdot 7 \mathrm{H}_{2} \mathrm{O}$ растворяется в $\mathrm{H}_{2} \mathrm{O}$, а на втором $\mathrm{Fe}(\mathrm{OH})_{2}$ окисляется до $\mathrm{Fe}(\mathrm{OH})_{3}$ кислородом окружающей среды. В конечном итоге в щелочных условиях среды экстракта картофеля образовывались наноструктуры $\mathrm{Fe}_{3} \mathrm{O}_{4}$. Согласно данным СЭМ и ПЭМ, полученные наночастицы $\mathrm{Fe}_{3} \mathrm{O}_{4}$ кубической формы, а их средний размер равен $40 \pm 2$ нм.

Сообщалось о зеленом синтезе наночастиц железа с использованием экстракта цветов Piliostigma thonningii, принадлежащего семейству бобовых. Для синтеза наночастиц 10 мл экстракта смешали с 90 мл 0,001 М раствора $\mathrm{FeCl}_{2}$, после чего в течение двух минут наблюдалось изменение цвета раствора от коричневого до кирпично-красного, что указывало на образование наночастиц железа. После этого полученные частицы отделяли центрифугированием, промывали дистиллированной водой и сушили при $80{ }^{\circ} \mathrm{C}$. Однако, согласно данным СЭМ, полученные наночастицы сформировали крупные агломераты (от 20 до 100 мкм) в виде неправильных прямо- угольных, стержневидных и сферических форм с шероховатыми поверхностями [30].

R. Sheykhbaglouc соавт. [31] оценивали влияние наночастиц оксида железа $\mathrm{Fe}_{2} \mathrm{O}_{3}$ на процентное содержание белка, липидов и жирных кислот, включая линолевую, пальмитиновую, олеиновую и линоленовую кислоты. В результате было обнаружено, что внекорневое опрыскивание растений сои нанооксидом железа концентрацией 0,75 г/л привело к увеличению содержания белка до $34 \%$ и липидов до $25 \%$ по сравнению с контролем, в котором их содержание достигало 28 и $20 \%$ соответственно. Кроме того, при использовании концентрации 0,75 г/л доля олеиновой кислоты увеличилась на $3 \%$, а доля линолевой на $5 \%$. Тогда как самый высокий уровень линоленовой кислоты (11\%) наблюдался при обработке наночастицами концентрацией 0,50 г/л и был на $1 \%$ выше, чем в контроле. Помимо содержания органических кислот, наночастицы оксида железа концентрацией 0,75 г/л повлияли на минеральный состав семян. Так, содержание железа, магния, фосфора и кальция увеличилось на 1,7, 3,3, 4,0 и 3,7 мг/г соответственно по сравнению с контролем. К тому же при обработке растений наночастицами $\mathrm{Fe}_{2} \mathrm{O}_{3}$ концентрацией 0,75 г/л увеличилось содержание хлорофилла в семенах сои, что могло положительно повлиять на антиоксидантную роль соевого масла, обеспечивая благоприятный эффект с точки зрения пищевой науки и технологий.

В работе [32] изучалось влияние наночастиц железа на фотосинтез и связанную с ним биохимическую адаптацию выращенной в почве резуховидки Таля (Arabidopsis thaliana L.). После обработки наночастицами концентрацией 500 мг железа на кг почвы биомасса растений увеличилась на $38 \%$ за счет усиления фотосинтеза, что было подтверждено системой газообмена, соотношением изотопов углерода и анализом содержания хлорофилла. Кроме того, потребление железа увеличивалось корнями и листьями растения. Измерения магнитных свойств и просвечивающая электронная микроскопия показали, что трансформированные частицы накапливались в частях тканей растений. Накопление углеводов, таких как глюкоза, сахароза и крахмал, увеличивалось за счет усиленного фотосинтеза, а связанные с фотосинтезом неорганические питательные вещества, такие как фосфор, марганец и цинк, поддерживают гомеостаз в соответствии с повышенным потреблением железа. 
Эти данные свидетельствовали о том, что наночастицы железа обладают дополнительными или альтернативными преимуществами в качестве наноудобрения и стимулятора поглощения $\mathrm{CO}_{2}$ растениями.

Получение и применение наночастиц, меди и оксида меди в растениеводстве. Удобрения на основе меди чаще всего используются в рецептурах для защиты растений. Это важный микронутриент, который входит в состав многих белков и ферментов и играет важную роль в здоровье и питании растений. Применение наночастиц меди в качестве бионаноудобрений и биотвердых веществ на сельскохозяйственных полях может стать возможным способом воздействия на растения. Медь является жизненно важным микронутриентом для растений и животных и крайне необходима для различных важных физиологических и биологических функций, таких как клеточная транспортировка, митохондриальное дыхание, транспорт белков, антиоксидантная активность и передача сигналов гормонов растений [10].

N. Jayarambabu c соавт. [33] для синтеза наночастиц меди использовали водный экстракт куркумина, полученный из клубней куркумы (Curcuma longa L.) и 0,1 М раствора дигидрата ацетата меди, смесь (объемное соотношение 1:2) которых нагревали в микроволновой печи в течение 180 с (мощность 200 Вт). Изменение цвета раствора с желтого на кирпичнокоричневый свидетельствовало о формировании наночастиц меди, размер которых, согласно данным ПЭМ, варьирует от 5 до 20 нм.

Наночастицы меди и оксида меди были синтезированы с использованием экстракта фиников без косточек в качестве восстановителя. Для синтеза наночастиц меди и оксида меди $\mathrm{Cu}_{2} \mathrm{O}$ к 100 мл экстракта добавили 1 грамм цетилтриметиламмония бромида (ЦТАБ), а затем рН смеси доводили до 6,8, а температуру повышали до $80{ }^{\circ} \mathrm{C}$, после чего к смеси по капле добавляли раствор пентагидрата сульфата меди (0,1 г соли растворили в 10 мл дистиллированной воды). Реакцию продолжали при перемешивании до появления красновато-коричневого цвета, указывающего на успешное получение наночастиц $\mathrm{Cu} / \mathrm{Cu}_{2} \mathrm{O}$. Согласно данным ПЭМ, полученные наночастицы имеют сферическую форму со средним диаметром 78 нм [34].

В работе [35] наночастицы оксида меди были синтезированы с использованием экстракта папоротника Adiantum lunulatumи 0,001 М раствора сульфата меди, которые смешали в объемном соотношении 5:1. О формировании наночастиц оксида меди свидетельствовало изменение цвета раствора с коричневого на зеленый, который обусловлен возбуждением поверхностных плазмонных колебаний частиц оксида меди. Размер частиц варьировал в диапазоне от 1 до 20 нм, а средний диаметр составил 7 нм. Был оценен потенциал полученных наночастиц в индукции защиты и генерации окислительного стресса на чечевице пищевой (Lens culinaris), которую использовали в качестве модельного растения. Для проведения модельного эксперимента на растениях, семена чечевицы пищевой были замочены в чашках Петри, содержащих воду (контроль) и различные концентрации наночастиц $\mathrm{CuO}$ $(0,01,0,025$ и 0,05 мг/мл), и выдержаны в темноте в течение 72 ч при $30^{\circ} \mathrm{C}$. В результате процент прорастания семян увеличился в 1,2 и 1,1 раза у семян, обработанных наночастицами $\mathrm{CuO}$ концентрацией 0,01 и 0,025 мг/мл по сравнению с контролем, тогда как при высокой концентрации наночастиц всхожесть семян существенно уменьшилась, что говорит о токсическом воздействии высоких концентраций меди. Аналогично проценту прорастания семян увеличился и индекс всхожести. При этом наночастицы оксида меди не повлияли на относительное содержание воды в обработанных корнях, которое равно $87 \pm 4 \%$ для контроля, $88 \pm 4 \%, 84 \pm 5$ и $81 \pm 4 \%$ для концентраций $0,01,0,025$, и 0,05 мг/мл соответственно. Кроме того, при концентрации наночастиц 0,025 мг/мл возросла индуктивная способность всех защитных ферментов растения. В частности, активность каталазы и супероксид дисмутазы увеличивались прямо пропорционально с возрастанием концентрации наночастиц. При этом самый высокий прирост активности был отмечен в корнях растений, что в 2,13 и 1,46 раза выше по сравнению с контролем. Повышенная концентрация антиоксидантных ферментов указывает на высокую степень устойчивости растений к окислительному стрессу. Кроме того, семена, обработанные наночастицами концентрацией 0,025 мг/мл, были устойчивее к внешним патогенам за счет более высокого содержания фенола и флавоноидов (в 1,76 и 2,33 раза больше по сравнению с контролем). В целом наблюдения показывают, что наночастицы $\mathrm{CuO}$ в оптимальной концентрации не только потенциально способны влиять на физиологическое состояние, но также могут модулиро- 
вать врожденную иммунную систему модельных растений, таких как чечевица [35].

P. Naga Padma c соавт. [36] синтезировали наночастицы меди с использованием экстрактов различных растений, таких как клещевина (Ricinus communis L.), гранат обыкновенный (Punica granatum L.), гуава (Psidium guajava L.), эвкалипт шаровидный (Eucalyptus globules), базилик тонкоцветный (Ocimum tenuiflorum L.), бархатцы (Tagetes sp.), индийский крыжовник (Phyllanthus emblica L.) и 0,001 M водного раствора сульфата меди. Согласно спектрам поглощения наночастиц меди в УФ и видимой области, скорость восстановления ионов меди с использованием различных экстрактов листьев находится в следующем порядке: бархатцы < клещевина < эвкалипт шаровидный < гуава < базилик тонкоцветный $<$ индийский крыжовник < гранат обыкновенный. СЭМ-изображения показали, что наночастицы меди, приготовленные с использованием экстракта кожуры плодов граната, имели сферическую форму с диаметром 56-59 нм.

В работе [37] синтезировали наночастицы оксида меди с использованием сока сахарного тростника (Saccharum officinarum L.). Для синтеза наночастиц сок различного объема (2, 5 и 10 мл) смешивали со 100 мл 0,1 М раствора нитрата меди. После изменения цвета реакционной смеси с синего на зеленый к вышеуказанному раствору по каплям добавляли избыточное количество 0,5 М гидроксида аммония до тех пор, пока $\mathrm{pH}$ не достигал 10 при интенсивном перемешивании. После добавления гидроксида аммония цвет раствора стал темно-коричневым. Реакцию смеси продолжали на магнитной мешалке в течение 8 ч до образования геля. Чтобы удалить свободные нитрат-ионы и органические примеси, а также избыток аммиака, полученный осадок центрифугировали, тщательно промывали дистиллированной водой и нагревали в сушильном шкафу 8 ч при $80^{\circ} \mathrm{C}$. Материал прокаливали три часа при $500{ }^{\circ} \mathrm{C}$ в муфельной печи для превращения гидроксида в оксид меди. Согласно данным СЭМ и ПЭМ, полученные наночастицы имеют сферическую форму. Однако их размер зависит от объема добавленного сока и равен 60, 40 и 29 нм при добавлении 2, 5 и 10 мл сока соответственно.

K. Mandava c соавт. [38] синтезировали наночастицы меди с использованием экстракта зеленого чая и водного раствора $\mathrm{CuSO}_{4} \cdot 5 \mathrm{H}_{2} \mathrm{O}$ (концентрация $0,001 \mathrm{M}$ ). О формировании наночастиц свидетельствовало изменение цвета раствора с темно-зеленого на цвет морской волны. Согласно данным СЭМ, размер полученных наночастиц варьировал от 67 до 99 нм.

S. C. Mali c coaвт. [39] получили наночастицы $\mathrm{CuO}$, используя экстракт растения Enicostemma axillareи 0,005 М раствор сульфата меди. При этом о формировании наночастиц свидетельствовало изменение цвета от красновато-коричневого до зеленого и образование вязкого осадка при $\mathrm{pH}=7,0$. Согласно данным ПЭМ, полученные наночастицы весьма однородны по размеру, и средний размер частиц составляет 6 нм.

Наночастицы $\mathrm{CuO}$ овальной формы и размером от 0,1 до 0,25 мкм были синтезированы с использованием водного экстракта листьев птероспермума кленолистного (Pterospermum acerifolium) и тригидрата нитрата меди, смешанных в стехиометрическом соотношении при постоянном перемешивании при 45-50 ${ }^{\circ} \mathrm{C}$ пока цвет раствора не изменился с синего на темно-зеленый. После чего смесь помещали в печь при $400{ }^{\circ} \mathrm{C}$ на пять минут, в результате чего был получен порошок черного цвета, содержащий наночастицы $\mathrm{CuO}$ [40].

S. Hemmatic соавт. [41] синтезировали сферические наночастицы $\mathrm{CuO}$ размером 15-25 нм, используя водный экстракт плодов шиповника (Rosa canina), который по каплям (10 мл) добавили в 100 мл раствора ацетата меди (концентрация 0,001 M), затем его кипятили при $100{ }^{\circ} \mathrm{C}$ в течение часа. При этом цвет раствора со временем стал темно-коричневый из-за возбуждения поверхностного плазмонного резонанса, сигнализирующего о получении наночастиц $\mathrm{CuO}$.

В работе [42] описан метод получения наночастиц меди путем биологического восстановления ионов $\mathrm{Cu}$ водным экстрактом липы, который добавляли к раствору пентагидрата сульфата меди в объемном соотношении 4:1 и нагревали смесь при $80{ }^{\circ} \mathrm{C}$ в течение 25 минут, а после оставляли в темноте на 24 часа для отстаивания. Полученные частицы $\mathrm{Cu}$ имели сферическую форму с различным диаметром частиц в диапазоне от 5 до 17 нм.

K. Cota-Ruiz c coaвт. [43] выращивали люцерну (Medicago sativa) в почвенной смеси, добавляя в почву соединения меди в виде наночастиц и в ионной форме (концентрации 80 и 280 мг $\mathrm{Cu} /$ кг почвы), а затем оценили производительность растений на физиологическом и молекулярном уровнях. В растениях, подвергнутых воздействию меди в различных формах, снизилось содержание фосфора и серы по сравнению с контролем $(\mathrm{p} \leq 0,05)$. Кроме того, благодаря добавкам меди в почве 
увеличилось содержание железа и цинка в корнях и железа в листьях растений по сравнению с контролем $(\mathrm{p} \leq 0,05)$. Экспрессия листовой супероксиддисмутазы увеличилась приблизительно в 29 раз в растениях, обработанных наночастицами меди концентрацией 280 мг/кг по сравнению с контролем $(\mathrm{p} \leq 0,05)$. Кроме того, под воздействием меди возросло относительное количество микроорганизмов, участвующих в поглощении элементов. Так, количество актинобактерий и сахарибактерий увеличилось в 1,3 и 1,6 раза соответственно по сравнению с контролем. Эти результаты показали, что нано-Сu улучшила физиологию люцерны и может рассматриваться как потенциальное наноудобрение [43].

Цель исследования [44] состояла в том, чтобы оценить влияние наночастиц $\mathrm{CuO}$ на изменения в структуре бактериального сообщества и функций, связанных с круговоротом азота в почве с высоким $\mathrm{pH}$, и сопоставить эти изменения с накоплением нитратов, изменениями параметров почвы и ростом растений. В течение 28 дней на проростки мягкой пшеницы (Triticum aestivum L.) воздействовали наночастицами $\mathrm{CuO}$ (концентрация 50 мг/кг почвы), $\mathrm{CuSO}_{4}$ концентрацией 50 мг/кг, или 0,5 мг/кг в стандартной почве (почва Lufa 2.1, $\mathrm{pH}$ доведен до 7,6). Обработка $\mathrm{Cu}$ уменьшала накопление нитратов в основной массе почвы, тогда как в ризосфере эффекты были противоположными (почва находилась под влиянием корневых экссудатов). При этом накопление нитратов в основной массе почвы отрицательно коррелировало с общей концентрацией $\mathrm{Cu}$, а часть концентрации нитратов в ризосфере объяснялась поглощением корнями во время роста растений, а остальная часть модулировалась обработкой $\mathrm{Cu}$.

Два наноматериала меди (наночастицы $\mathrm{CuO}$ и нанолисты $\left.\left.\mathrm{Cu}_{3}\left(\mathrm{PO}_{4}\right)_{2} \cdot 3 \mathrm{H}_{2} \mathrm{O}\right)\right)$ и $\mathrm{CuSO}_{4}$ были нанесены на листья томатов (Solanum lycopersicum L.), и элементарное движение $\mathrm{Cu}$ с поверхности листа через кутикулу во внутреннюю ткань листа наблюдали более 8 часов. Две формы наноразмерной меди использовали для внекорневой обработки томатов еженедельно в тепличных и полевых экспериментах в присутствии патогена Fusarium oxysporum. Для $\mathrm{CuSO}_{4}$ накопление и удерживание $\mathrm{Cu}$ в кутикуле было в 7 раз больше, чем в наноматериалах, демонстрируя, что наноразмерная морфология и состав опосредуют накопление $\mathrm{Cu}$ в ткани листа. В теплице еженедельная листовая подкормка нанолистами и наночасти- цами увеличивала биомассу проростков на 91 и $93 \%$, соответственно, по сравнению с зараженными Fusarium oxysporum и обрабатываемыми $\mathrm{CuSO}_{4}$ растениями. В полевом эксперименте нанолисты $\mathrm{Cu}_{3}\left(\mathrm{PO}_{4}\right)_{2} \bullet 3 \mathrm{H}_{2} \mathrm{O}$ снизили прогрессирование болезни на $26 \%$ и значительно повысили урожайность плодов более чем на 45 \% с одного растения по сравнению с другими обработками на пораженной почве. Эти результаты показали, что химические свойства питательных веществ в наномасштабе могут быть настроены таким образом, чтобы максимизировать и контролировать их движение через кутикулу, и что взаимодействия на листьях проростков могут принести пользу в течение всего сезона для выращивания томатов, даже в присутствии возбудителя [45].

Получение и применение наночастиц марганцуа и оксида марганцуа в растениеводстве. Марганец (Mn) играет жизненно важную роль не только в метаболических и физиологических процессах, но также дает растениям способность выдерживать различные стрессы окружающей среды, действуя как кофактор различных ферментов. Он также важен для фотосинтеза, биосинтеза АТФ, хлорофилла, жирных кислот и белков, а также вторичных метаболитов, таких как лигнин и флавоноиды [3].

S. A. Khan c coaвт. [46] синтезировали наночастицы $\mathrm{MnO}$ с использованием экстракта листьев канатника индийского (Abutilon indicum) в качестве восстановителя и стабилизатора. Экстракт смешивали с $0,1 \mathrm{M}$ раствором $\mathrm{MnSO}_{4}$ в объемном соотношении 1:1 и по каплям добавляли $0,1 \mathrm{M}$ раствор $\mathrm{NaOH}$ до получения $\mathrm{pH}=8,0$ при постоянном перемешивании при $50{ }^{\circ} \mathrm{C}$ в течение часа. Образовавшийся осадок промывали, высушивали и прокаливали при $150{ }^{\circ} \mathrm{C}$ в течение двух часов. Согласно данным СЭМ, в результате были получены наночастицы $\mathrm{MnO}$ сферической формы со средним размером $80 \pm 0,5$ нм.

Наночастицы $\mathrm{MnO}_{2}$ были синтезированы с использованием водного экстракта ктенолеписа (Ctenolepis garcinii) и 0,001 М раствора перманганата калия, которые смешивали в объемном соотношении 1:5. При этом цвет раствора стал красным из-за явления поверхностного плазмонного резонанса, свидетельствуя о формировании наночастиц $\mathrm{MnO}_{2}$, которые отделяли от реакционной смеси центрифугированием, промывали и высушивали. Результаты СЭМ показали, что диаметр приготовленных наночастиц в растворе составил около 57-69 нм [47]. 
В работе [48] был описан синтез наночастиц $\mathrm{MnO}_{2}$ из 0,01 мМ раствора ацетата марганца и экстракта юкки славной (Yucca gloriosa). B процессе синтеза частиц при комнатной температуре варьировалось соотношение экстракта и прекурсора, $\mathrm{pH}(4,6$ и 8$)$ и время реакции (40, 80 и 120 минут). В результате было обнаружено, что наиболее оптимальными условиями реакции, при которых сформировались сферические наночастицы $\mathrm{MnO}_{2}$ диаметром 35 нм, являются $\mathrm{pH}=8$ и время реакции 120 минут.

В лабораторных условиях было установлено, что наночастицы марганца эффективнее, чем коммерчески доступная соль марганца $\left(\mathrm{MnSO}_{4}\right)$ в рекомендуемых дозах при проращивании бобов маше (Vigna radiata). В более высоких дозах наночастицы не токсичны для растений, в отличие от соли марганца. Биохимическими и биофизическими методами было выявлено, что хлоропласты, обработанные наночастицами $\mathrm{Mn}$, демонстрировали большее фотофосфорилирование и выделение кислорода по сравнению с контрольными и обработанными $\mathrm{MnSO}_{4}$ хлоропластами. Расщепление воды комплексом, выделяющим кислород, усиливалось наночастицами $\mathrm{Mn}$ в изолированном хлоропласте, что подтверждается полярографическими и спектроскопическими методами [49].

В работе [50] наночастицы оксида марганца (III) были исследованы в качестве вещества, снижающего соленость в стручковом перце (Capsicum annuит L.) во время проращивания при использовании $100 \mathrm{MM} \mathrm{NaCl}$. В целом рост корней как не подвергнутых, так и подвергнутых солевому стрессу проростков был значительно улучшен за счет наночастиц оксида марганца, концентрация которых составила $0,1,0,5,1,0$ мг/л. Сканирующая электронная микроскопия и энергодисперсионный рентгенофлуоресцентный анализ показали проникновение наночастиц через семенную оболочку и образование комплекса наночастиц с короной. Наночастицы оксида марганца позволяют снизить солевой стресс за счет того, что в присутствии наночастиц изменяется химический состав поверхности семян, что может привести к изменению процесса связывания N-H в соответствии с инфракрасной спектроскопией с преобразованием Фурье. Солевой стресс подавлял рост корней и вызывал изменения структуры белков и лигнина, перераспределял содержание марганца, натрия, калия и кальция между побегом и корнем. Данное исследование объяснило, какие изменения состава и молекулярных взаимодей- ствий между ключевыми биомолекулами вызывает нанонагрузка за счет использования наночастиц оксида $\mathrm{Mn}$.

Заключение. Для биосинтеза наночастиц таких металлов, как цинк, медь, железо и марганец, а также их оксидов могут быть использованы различные виды растений, находящиеся в шаговой доступности от исследователя. При этом, как показано в обзоре, в используемых растениях в большом количестве содержатся различные химически активные танины, сапонины, полифенолы, алкалоиды, эфирные масла, стероиды и другие вторичные метаболиты, за счет которых ионы восстанавливаются до наночастиц металлов и их оксидов. Согласно описанным в основной части обзора работам, весь процесс биосинтеза наночастиц металлов и оксидов металлов с использованием растительных экстрактов можно разделить на несколько этапов: 1) приготовление растительного экстракта; 2) смешивание экстракта с раствором прекурсора металла (как правило, в качестве прекурсоров металлов используют недорогие коммерчески доступные соли (нитраты, сульфаты и ацетаты)); 3) инкубация полученной смеси при определенной температуре и в некоторых случаях применение ультразвукового воздействия или высокого давления; 4) отделение и очистка полученных наночастиц; 5) прокаливание наночастиц при высоких температурах.

Для синтеза наночастиц могут быть использованы различные части растения. При этом стоит учитывать, что как различные растения, так и их составные части могут содержать неодинаковое количество биологически активных веществ. Следовательно, различие в концентрации биомолекул среди многих растений и их результирующее взаимодействие с водными ионами металлов можно считать одним из ключевых факторов, связанных с разнообразием размеров и форм производимых наночастиц. Также важно отметить, что экстракты, полученные из разных видов растений и частей одного и того же растения, могут иметь различные значения $\mathrm{pH}$, что влияет на характер образующихся наночастиц.

В целом использование наночастиц металлов и их оксидов в качестве удобрений положительно сказывается на растительных организмах за счет того, что наночастицам легче проникнуть через растительную мембрану, а также перейти в доступную для растений форму по сравнению с обычными аналогами. Положительный эффект влияния наночастиц на растения выражается в удли- 
нении корней и побегов растений, увеличении прироста биомассы проростков. Кроме того, в листьях увеличивается количество хлорофилла, а также изменяются некоторые биохимические процессы, ведущие, например, к накоплению антиоксидантных ферментов, что позволяет повысить стрессоустой- чивость растений. Исходя из всего вышесказанного можно сделать вывод, что использование наночастиц металлов и их оксидов в качестве компонента удобрений и препаратов для растениеводства является перспективным направлением и будет использовано в нашей дальнейшей работе.

\section{Список литературы}

1. Liu R., Lal R. Potentials of engineered nanoparticles as fertilizers for increasing agronomic productions. Science of the Total Environment. 2015;514:131-139. DOI: https://doi.org/10.1016/j.scitotenv.2015.01.104

2. Calabi-Floody M., Medina J., Rumpel C., Condron L. M., Hernandez M., Dumont M., de la Luz Mora M. Smart fertilizers as a strategy for sustainable agriculture. Advances in Agronomy. 2018;147:119-157. DOI: https://doi.org/10.1016/bs.agron.2017.10.003

3. Sekhon B. S. Nanotechnology in agri-food production: an overview. Nanotechnology. Science and Applications. 2014;7:31-53. DOI: https://doi.org/10.2147/NSA.S39406

4. Zulfiqara F., Navarro M., Ashraf M., Akrame N. A., Munné-Bosch S. Nanofertilizer use for sustainable agriculture: Advantages and limitations. Plant Science. 2019;289:11027.

DOI: https://doi.org/10.1016/j.plantsci.2019.110270

5. Jamkhande P. G., Ghule N. W., Bamer A. H., Kalaskar M. G. Metal nanoparticles synthesis: An overview on methods of preparation, advantages and disadvantages, and applications. Journal of drug delivery science and technology. 2019;53:101174. DOI: https://doi.org/10.1016/j.jddst.2019.101174

6. Dhand C., Dwivedi N., Loh X. J., Ying A. N. J., Verma N. K., Beuerman R. W., Lakshminarayanan R., Ramakrishna S. Methods and strategies for the synthesis of diverse nanoparticles and their applications: a comprehensive overview. RSC Advances.2015;5:105003-105037. DOI: https://doi.org/10.1039/C5RA19388E

7. Vitta Y., Figueroa M., Calderon M., Ciangherotti C. Synthesis of iron nanoparticles from aqueous extract of Eucalyptus robusta $\mathrm{Sm}$ and evaluation of antioxidant and antimicrobial activity. Materials science for energy technologies. 2020;3:97-103. DOI: https://doi.org/10.1016/j.mset.2019.10.014

8. Singh A., Gautam P. K., Verma A., Singh V., Shivapriya P. M., Shivalkar S., Sahoo A. K., Samanta S. K. Green synthesis of metallic nanoparticles as effective alternatives to treat antibiotics resistant bacterial infections: A review. Biotechnology Reports. 2020;25:e00427. DOI: https://doi.org/10.1016/j.btre.2020.e00427

9. Chokkareddy R., Redhi G. G. Green Synthesis of metal nanoparticles and its reaction mechanisms. Green metal nanoparticles. 2018:113-139. DOI: https://doi.org/10.1002/9781119418900.ch4

10. Priyanka N., Geetha N., Ghorbanpour M., Venkatachalam P. Role of engineered zinc and copper oxide nanoparticles in promoting plant growth and yield: present status and future prospects. Advances in Phytonanotechnology. 2019;6:183-201. DOI: https://doi.org/10.1016/B978-0-12-815322-2.00007-9

11. Saha R., Karthik S., Balu K. S., Suriyaprabha R., Siva P., Rajendran V. Influence of the various synthesis methods on the $\mathrm{ZnO}$ nanoparticles property made using the bark extract of Terminalia arjuna. Materials Chemistry and Physics. 2018;209:208-216. DOI: https://doi.org/10.1016/j.matchemphys.2018.01.023

12. Rajabi H. R., Naghiha A., Kheirizdeh M., Sadatfaraji H., Mirzaei A., Alvand Z. M. Microwave assisted extraction as an efficient approach for biosynthesis of zinc oxide nanoparticles: Synthesis, characterization, and biological properties. Materials Science and Engineering. 2017;78:1109-1118. DOI: https://doi.org/10.1016/j.msec.2017.03.090

13. Lu J., Ali H., Hurh J., Han Y., Batjikh I., Rupa E. J., Anandapadmanaban G., Park J. K., Yang D.-C. The assessment of photocatalytic activity of zinc oxide nanoparticles from the roots of Codonopsis lanceolata synthesized by one-pot green synthesis method. Optik - International Journal for Light and Electron Optics. 2019;184:82-89. DOI: https://doi.org/10.1016/j.ijleo.2019.03.050

14. Nilavukkarasi M., Vijayakumar S., Prathipkumar S. Capparis zeylanica mediated bio-synthesized ZnO nanoparticles as antimicrobial, photocatalytic and anti-cancer applications. Materials Science for Energy Technologies. 2020;3:335-343. DOI: https://doi.org/10.1016/j.mset.2019.12.004

15. Ahmad W., Kalra D. Green synthesis, characterization and anti microbial activities of $\mathrm{ZnO}$ nanoparticles using Euphorbia hirta leaf extract. Journal of King Saud University - Science. 2020;32(4):2358-2364. DOI: https://doi.org/10.1016/j.jksus.2020.03.014

16. Elumalai K., Velmurugan S., Ravi S., Kathiravan V., Ashokkumar S. RETRACTED: Facile, eco-friendly and template free photosynthesis of cauliflower like $\mathrm{ZnO}$ nanoparticles using leaf extract of Tamarindus indica (L.) and its biological evolution of antibacterial and antifungal activities. Spectrochimica Acta Part A: Molecular and Biomolecular Spectroscopy. 2015;136 (Part B):1052-1057. DOI: https://doi.org/10.1016/j.saa.2014.09.129

17. Zare E., Pourseyedi S., Khatami M., Darezereshki E. Simple biosynthesis of zinc oxide nanoparticles using nature's source, and it's in vitro bio-activity. Journal of Molecular Structure. 2017;1146:96-103. DOI: https://doi.org/10.1016/j.molstruc.2017.05.118

18. Santhoshkumar J., Venkat Kumar S., Rajeshkumar S. Synthesis of zinc oxide nanoparticles using plant leaf extract against urinary tract infection pathogen. Resource-Efficient Technologies. 2017;3(4):459-465. DOI: https://doi.org/10.1016/j.reffit.2017.05.001 
19. Karnan T., Selvakumar S. A. S. Biosynthesis of $\mathrm{ZnO}$ nanoparticles using rambutan (Nephelium lappaceum L.) peel extract and their photocatalytic activity on methyl orange dye. Journal of Molecular Structure. 2016;1125:358-365. DOI: https://doi.org/10.1016/j.molstruc.2016.07.029

20. Raliya R., Tarafdar J. C. ZnO nanoparticle biosynthesis and its effect on phosphorous-mobilizing enzyme secretion and gum contents in clusterbean (Cyamopsis tetragonoloba L.). Agric Res. 2013;2:48-57. DOI: https://doi.org/10.1007/s40003-012-0049-z

21. Mazumder J. A., Khan E., Perwez M., Gupta M., Kumar S., Raza K., Sardar M. Exposure of biosynthesized nanoscale $\mathrm{ZnO}$ to Brassica juncea crop plant: morphological, biochemical and molecular aspects. Scientific Reports. 2020;10:8531. DOI: https://doi.org/10.1038/s41598-020-65271-y

22. Yusefi-Tanha E., Fallah S., Rostamnejadi A., Pokhrel L. R. Zinc oxide nanoparticles (ZnONPs) as a novel nanofertilizer: Influence on seed yield and antioxidant defense system in soil grownsoybean (Glycine max cv. Kowsar). Science of the Total Environment. 2020;738:140240. DOI: https://doi.org/10.1016/j.scitotenv.2020.140240

23. Nandhini M., Rajini S. B., Udayashankar A. C., Niranjana S. R., Lund O. S., Shetty H. S., Prakash H. S. Biofabricated zinc oxide nanoparticles as an eco-friendly alternative for growth promotion and management of downy mildew of pearl millet. Crop Protection. 2019;121:103-112. DOI: https://doi.org/10.1016/j.cropro.2019.03.015

24. Zhang T., Sun H., Lv Z., Cui L., Mao H., Kopittke P. M. Using synchrotron-based approaches to examine the foliar application of $\mathrm{ZnSO} 4$ and $\mathrm{ZnO}$ nanoparticles for field-grown winter wheat. Journal of Agricultural and Food Chemistry. 2018;66(11):2572-2579. DOI: https://doi.org/10.1021/acs.jafc.7b04153

25. Asghar M. A., Zahir E., Shahid S. M., Khan M. N., Asghar M. A., Iqbal J., Walker G. Iron, copper and silver nanoparticles: Green synthesis using green and black tea leaves extracts and evaluation of antibacterial, antifungal and aflatoxin B1 adsorption activity. LWT - Food Science and Technology. 2018;90:98-107. DOI: https://doi.org/10.1016/j.lwt.2017.12.009

26. Karade V. C., Dongale T. D., Sahoo S. C., Kollu P., Chougale A. D., Patil P. S., Patil P. B. Effect of reaction time on structural and magnetic properties of greensynthesized magnetic nanoparticles. Journal of Physics and Chemistry of Solids. 2018;120:161-166. DOI: https://doi.org/10.1016/j.jpcs.2018.04.040

27. Desalegn B., Megharaj M., Chen Z., Naidu R. Green synthesis of zero valent iron nanoparticle using mango peel extract and surface characterization using XPS and GC-MS. Heliyon. 2019;5:e01750. DOI: https://doi.org/10.1016/j.heliyon.2019.e01750

28. Sathishkumar G., Logeshwaran V., Sarathbabu S., Jha P. K., Jeyaraj M., Rajkuberan C., Senthilkumar N., Sivaramakrishnan S. Green synthesis of magnetic Fe3O4 nanoparticles using Couroupitaguianensis Aubl. fruit extract for their antibacterial and cytotoxicity activities. Artificial Cells, Nanomedicine, and Biotechnology. 2018;46(3):589-598. DOI: https://doi.org/10.1080/21691401.2017.1332635

29. Buazar F., Baghlani-Nejazd M. H., Badri M., Kashisaz M., Khaledi-Nasab A., Kroushawi F. Facile onepot phytosynthesis of magnetic nanoparticles using potato extract and their catalytic activity. Starch/Stärke. 2016;68(7-8):796-804. DOI: https://doi.org/10.1002/star.201500347

30. Igwe O. U., Nwamezie F. Green synthesis of iron nanoparticles using flower extract of Piliostigma thonningii and their antibacterial activity evaluation. Chemistry International. 2018;4(1):60-66.

31. Sheykhbaglou R., Sedghi M., Fathi-Achachlouie B. The effect of ferrous nano-oxide particles on physiological traits and nutritional compounds of soybean (Glycine max L.) seed. Anais da Academia Brasileira de Ciências (Annals of the Brazilian Academy of Sciences). 2018;90(1):485-494.

DOI: https://doi.org/10.1590/0001-3765201820160251

32. Yoon H., Kang Y.-G., Chang Y.-S., Kim J.-H. Effects of zerovalent iron nanoparticles on photosynthesis and biochemical adaptation of soil-grown Arabidopsis thaliana. Nanomaterials. 2019;9(11):1543.

DOI: https://doi.org/10.3390/nano9111543

33. Jayarambabu N., Akshaykranth A., Rao T. V., Rao K. V., Kumar R. R. Green synthesis of Cu nanoparticles using Curcuma longa extract and their application in antimicrobial activity. Materials Letters. 2019;259:126813. DOI: https://doi.org/10.1016/j.matlet.2019.126813

34. Mohamed E. A. Green synthesis of copper and copper oxide nanoparticles using the extract of seedless dates. Heliyon. 2020;6:e03123. DOI: https://doi.org/10.1016/j.heliyon.2019.e03123

35. Sarkar J., Chakraborty N., Chatterjee A., Bhattacharjee A., Dasgupta D., Acharya K. Green synthesized copper oxide nanoparticles ameliorate defence and antioxidant enzymes in Lens culinaris. Nanomaterials. 2020;10(2):312-338. DOI: https://doi.org/10.3390/nano10020312

36. Padma P. N., Banu S. T., Kumari S. C. Studies on green synthesis of copper nanoparticles using Punica granatum. Annual Research \& Review in Biology. 2018;23(1):1-10. DOI: https://doi.org/10.9734/ARRB/2018/38894

37. Mary A. P. A., Ansari A. T., Subramanian R. Sugarcane juice mediated synthesis of copper oxide nanoparticles, characterization and their antibacterial activity. Journal of King Saud University - Science. 2019;31(4):1103-1114. DOI: https://doi.org/10.1016/j.jksus.2019.03.003

38. Mandava K., Kadimcharla K., Keesara N. R., Fatima S. N., Bommena P., Batchu U. R. Green synthesis of stable copper nanoparticles and synergistic activity with antibiotics. Indian Journal of Pharmaceutical Sciences. 2017;79(5):695-700. DOI: https://doi.org/10.4172/pharmaceutical-sciences.1000281

Аграрная наука Евро-Северо-Востока /

Agricultural Science Euro-North-East. 2021;22(5):627-640 
39. Mali S. C., Raj S., Trivedi R. Biosynthesis of copper oxide nanoparticles using Enicostemma axillare (Lam.) leaf extract. Biochemistry and Biophysics Reports. 2019;20:100699. DOI: https://doi.org/10.1016/j.bbrep.2019.100699

40. Saif S., Tahir A., Asim T., Chen Y. Plant mediated green synthesis of $\mathrm{CuO}$ nanoparticles: comparison of toxicity of engineered and plant mediated $\mathrm{CuO}$ nanoparticles towards Daphnia magna. Nanomaterials. 2016;6(11):205-219. DOI: https://doi.org/10.3390/nano6110205

41. Hemmati S., Mehrazin L., Hekmati M., Izadi M., Veisi H. Biosynthesis of CuO nanoparticles using Rosa canina fruit extract as a recyclable and heterogeneous nanocatalyst for $\mathrm{C}-\mathrm{N}$ Ullmann coupling reactions. Materials Chemistry and Physics. 2018;214:527-532. DOI: https://doi.org/10.1016/j.matchemphys.2018.04.114

42. Hassanien R., Husein D. Z., Al-Hakkani M. F. Biosynthesis of copper nanoparticles using aqueous Tilia extract: antimicrobial and anticancer activities. Heliyon. 2018;4(12):e01077.

DOI: https://doi.org/10.1016/j.heliyon.2018.e01077

43. Cota-Ruiz K., Ye Y., Valdes C., Deng C., Wang Y., Hernández-Viezcas J. A., Duarte-Gardea M., Gardea-Torresdey J. L. Copper nanowires as nanofertilizers for alfalfa plants: Understanding nano-bio systems interactions frommicrobial genomics, plantmolecular responses and spectroscopic studies. Science of the Total Environment. 2020;742:140572. DOI: https://doi.org/10.1016/j.scitotenv.2020.140572

44. Guan X., Gao X., Avellan A., Spielman-Sun E., Xu J., Laughton S., Yun J., Zhang Y., Bland G. D., Zhang Y., Zhang R., Wang X., Casman E. A., Lowry G. V. CuO nanoparticles alter the rhizospheric bacterial community and local Nitrogen cycling for wheat grown in a calcareous soil. Environmental Science \& Technology. 2020; 54 (14):8699-8709. DOI: https://doi.org/10.1021/acs.est.0c00036

45. Shen Y., Borgatta J., Ma C., Elmer W., Hamers R. J., White J. C. Copper nanomaterial morphology and composition control foliar transfer through the cuticle and mediate resistance to root fungal disease in tomato (Solanum lycopersicum). Journal of Agricultural and Food Chemistry. 2020;68(41):11327-11338. DOI: https://doi.org/10.1021/acs.jafc.0c04546

46. Khan S. A., Shahid S., Shahid B., Fatima U., Abbasi S. A. Green synthesis of MnO nanoparticles using Abutilon indicum leaf extract for biological, photocatalytic, and adsorption activities. Biomolecules. 2020;10(5):785-803. DOI: https://doi.org/10.3390/biom10050785

47. Paul J. J. P., Sakunthala M., Udhaya C. I. Green synthesis of manganese nanoparticles using the aqueous extract of Ctenolepis garcini (Burm. f.) C.B Clarke. International Journal of Botany Studies. 2017;2(5):71-75.

48. Souri M., Hoseinpour V., Ghaemi N., Shakeri A. Procedure optimization for green synthesis of manganese dioxide nanoparticles by Yucca gloriosa leaf extract. International Nano Letters. 2019;9:73-81. DOI: https://doi.org/10.1007/s40089-018-0257-z

49. Pradhan S., Patra P., Das S., Chandra S., Mitra S., Dey K. K., Akbar S., Palit P., Goswami A. Photochemical modulation of biosafe manganese nanoparticles on Vigna radiata: A detailed molecular, biochemical, and biophysical study. Environ. Sci. Technol. 2013;47(22):13122-13131. DOI: https://doi.org/10.1021/es402659t

50. Ye Y., Cota-Ruiz K., Hernández-Viezcas J. A., Valdés C., Medina-Velo I. A., Turley R. S., PeraltaVidea J. R., Gardea-Torresdey J. L. Manganese nanoparticles control salinity-modulated molecular responses in Capsicum annuum L. through priming: A sustainable approach for agriculture. ACS Sustainable Chemistry and Engineering. 2020;8(3):1427-1436. DOI: https://doi.org/10.1021/acssuschemeng.9b05615

\section{Сведения об авторах}

Рабинович Галина Юрьевна, доктор биол. наук, профессор, директор Всероссийского научноисследовательского института мелиорированных земель, ФГБНУ Федеральный исследовательский центр «Почвенный институт имени В. В. Докучаева», Пыжевский пер., д. 7, стр. 2, г. Москва, Российская Федерация, 119017, e-mail: 2016vniimz-noo@list.ru, ORCID: https://orcid.org/0000-0002-5060-6241

$\triangle$ Любимова Надежда Андреевна, кандидат хим. наук, научный сотрудник отдела биотехнологий Всероссийского научно-исследовательского института мелиорированных земель, ФГБНУ Федеральный исследовательский центр «Почвенный институт имени В. В. Докучаева», Пыжевский пер., Д. 7, стр. 2, г. Москва, Российская Федерация, 119017, e-mail: 2016vniimz-noo@,list.ru,

ORCID: https://orcid.org/0000-0002-5831-5000, e-mail: n.nemygina@gmail.com

\section{Information about the authors}

Galina Yu. Rabinovich, DSc in Biological science, professor, Director All-Russian Research Institute of Reclaimed Lands, Federal Research Centre V. V. Dokuchaev Soil Science Institute, 7, bld. 2, Pyzhevsky per., Moscow, Russian Federation, 119017, e-mail: 2016vniimz-noo@list.ru,

ORCID: https://orcid.org/0000-0002-5060-6241

$\triangle$ Nadezhda A. Lyubimova, PhD in Chemicalscience, researcher the Department of Biotechnologies All-Russian Research Institute of Reclaimed Lands, Federal Research Centre V. V. Dokuchaev Soil Science Institute, 7, bld. 2, Pyzhevsky per., Moscow, Russian Federation, 119017, e-mail: 2016vniimz-noo@list.ru,

ORCID: https://orcid.org/0000-0002-5831-5000, e-mail: n.nemygina@gmail.com

- Для контактов / Corresponding author 